\title{
THE EFFECTIVENESS OF CHARADES GAME TOWARD STUDENTS' VOCABULARY MASTERY AT FOURTH GRADE OF SD UNGGULAN AISYIYAH BANTUL IN THE ACADEMIC YEAR OF 2016/2017
}

\author{
Demita Sari $^{1}$, Noor Chairani ${ }^{2}$ \\ ${ }^{1}$ University of Ahmad Dahlan \\ 1demita1300004149@webmail.uad.ac.id \\ ${ }^{2}$ University of Ahmad Dahlan
}

\begin{abstract}
This research is intended to find out the students' vocabulary mastery in experimental group who is taught by using Charades Game and in control group who is taught without using Charades Game and to find out whether there is a significant difference in English vocabulary mastery between the students in control group and the students in experimental group.

The experimental research was used in this research. The subjects of this research were conducted at fourth grade students of SD Unggulan Aisyiyah Bantul Yogyakarta. They were divided into four classes. There are two classes namely experimental group and control group that was taken in experimental research. The experimental group (IV B) consists of 31 students and the control group (IV D) also consists of 31 students. The data were collected by using vocabulary test.

The researcher used descriptive and inferential analysis to analyze the data, including the normality, homogeneity, and hypothesis test. The result of the pre-test showed mean score in experimental group is 54.67, while the mean of control group is 52.25. After the treatment, the mean score of the post-test in experimental group showed 81.77 and the mean score of control group showed 70.16. It means that the mean score of vocabulary mastery test of experimental group is higher than the mean score of control group. Then, the result of hypothesis using Indepentent T-test in the post-test showed that the level of significance is lower than 0.05 . i.e. $0.000<0.05$. Thus, $\mathrm{H}_{1}$ is accepted and $\mathrm{H}_{0}$ is rejected So, it can be stated that the use of Charades game has a good effect on students' vocabulary mastery.
\end{abstract}

Keywords: charades game, vocabulary mastery, experimental research.

\section{INTRODUCTION}

The first thing that people do in learning foreign language especially English is to master the vocabulary. A good mastery of vocabulary can help the learners in increasing the listening, speaking, reading and writing skill. By having a lot of words, learners will be able to understand the conversation with others, give a response, speak fluently, comprehend the reading materials, and write some kind of topics. On the other way, if the learners have limited vocabulary or can not recognize the meaning of the words, they will be unable to participate in the conversation, unable to express their ideas, or unable to ask for information. It is why the vocabulary becomes important in acquiring a foreign language.

Vocabulary should be learned from the beginning, it can start from elementary school. Generally, language learning is hard. In fact, the most students, especially in the fourth grade of SD Unggulan Aisyiyah Bantul, found some difficulties in mastering vocabulary. They are still difficult to memorize the new words. It can be seen when the students are given a test by the teacher, they find difficulties in answering the test because they miss some words. They also still find many difficulties in expressing their thought, being unconfident and shy to speak because of having limited vocabularies or no motivation to learn English. Those problems 
are caused by some factors, such as the students had low interest in learning English process. Based on the observation that the researcher did, the researcher found that some students did not pay more attention to the teacher. Consequently, they have nothing to do with a vocabulary learning so they are still difficult in remembering the meaning and pronouncing the word. Then, the problem also comes from the students' motivation in learning English such as; some students are busy in talking with their friend when their teacher explain about English materials, they tend to be passive, and they ignore teacher's instruction when they must do exercises.

Teaching vocabulary to young learners in elementary school is different from teaching vocabulary to adults. Because the young learners have different characteristics from adults. So, they need a special treatment. The teachers are expected to be creative in teaching English with using an interesting media. It is supported by Nation (2003) in Nunan and Caroline (2005: 122), the teacher should facilitate vocabulary learning by teaching learner useful words and by teaching strategies to help learner figure out meanings on their own. Students need to find the meaning of the word using strategies. When students are in the learning process, they can discover new words on their own and it makes students easy to remember. Many approaches and activities can be used to help students develop their vocabulary. One of the interesting strategies is games. According to Brewster and Ellis (2002: 172), games are not only motivating and fun but can also provide excellent practice for improving pronunciation, vocabulary, grammar and the four language skills. By using a game to teach vocabulary will engage the students to be more active because the game makes students have the enthusiasm to learn.

Related to all of that statements, the game for teaching vocabulary should be simple and easy. "Charades Game" is one of many games that can be applied in teaching English vocabulary. Charades is a fun game that any age level can participate in. The object of the game is to communicate a word by using gesture without any spoken word. The student would act each syllable of a word or phrase while the member of the group try to guess. It can be defined as party word guessing game. There are some reasons why the researcher chooses "Charades Game". First, "Charades Game" is one of simple class activities which makes the students more active and enjoyable during learning process because they learn by doing fun things. Second, "Charades Game" trains students to memorize the words because they are asked to guess by their understanding. Decarrico (2001) cited in Pourdana (2014: 213) states that words should not be learnt separately or by memorization without understanding. Thus, the researcher try to give the technique with charades game to see the effectiveness in improving students' vocabulary.

\section{LITERATURE REVIEW}

2.1 Review of Relevant Studies

There are two relevant studies in thia research. First, "The Effectiveness of Guessing Game to Teach Vocabulary for The Second Grade of SD Muhammadiyah Pringgokusuman Yogyakarta in Academic Year 2012/2013" written by Saryati (2013). Second, "The Effectiveness of Riddle Game to Teach Vocabulary for the Fifth Grade Students in SD Muhammadiyah Bodon Banguntapan in Academic Year of 2014/2015", written by Husna (2014). Their result studies showed that there was a significant different in effect on the English vocabulary mastery between the students taught by using both of guessing game and riddle game and the students taught without using these games. Their techniques are more effective than the 
conventional technique. In this research, the researcher is interested to make inovation in teaching vocabulary using different game, charades game.

\subsection{Review of Relevant Theories}

a. Characteristic of Young Learner

In the teaching foreign language at elementary school, the teacher should know the characteristics of the young learners in order to have effective teaching. Young learners have a great curiosity to try new thing. Cameron (2001: 2-3) states that the young learners actively try to construct the meaning from their experiences. It is supported by Harmer (2007: 82 ), young learners get their understanding not only from explanation but also from what they see and hear, learn when they have a chance to touch and interact with. Thus, the young learners learn something new by doing activities or experiences.

According Harmer (2007: 82 ) states that the young learners get bored easily and losing interest after ten minutes unless the activities are extremely engaging. Thus, the teacher should be able to keep students' concentration and attention. At this point, the characteristics are necessary for choosing an appropriate media in teaching English for young learners.

b. Theory of Vocabulary

1) Definition of Vocabulary

Vocabulary is a word that has a meaning. Cameron (2001: 72) states that vocabulary is central to the learning of foreign language at primary level. Based on Cameron's theory, vocabulary is being the first thing that students must be mastery. Before they learn four skills in English, students should have enough vocabulary because they can not catch other talking, give response, speak fluently, comprehend the reading materials, and write some kind of topic without mastering vocabulary. It is supported by Stahl and Nagy (2006: 4), state that words are the tools we use to access our background knowledge, express ideas, and learn new concepts. Thus, vocabulary is a group of words which have been mastered and to be used in communicating and expressing the learners' thought. That is the reason why it is important to learn vocabulary.

2) Vocabulary Mastery

Vocabulary is needed to be mastered by the learners in order to understand other people's saying and express their ideas. Mastery means a great skill which makes someone master or expert in a certain field. In learning language, the language learners who are good in mastery vocabulary can develop and use the language well. Vocabulary mastery itself deals with words and meaning. It is supported by Cameron (2001: 75), a person said to "know" a word if they can recognize its meaning when they see it. Thus, the language learners have to know the meaning of word and use it in a sentence. Similar with Cameron, Willis (2008: 80) also states that when the students build up vocabulary mastery, they can more effectively communicate their ideas, knowledge and voice. Thus, the mastery of vocabulary can be seen by the comprehension the word and using it in daily life to communicate with others.

3) Teaching Vocabulary For Young Learner

Young learner is an active learner. They have high curiosity about something new. They want to know about what they hear and they see and also they are being an active asking question about it. According to Hatch and Brown (1995: 373), there are five essential steps in learning vocabulary; students need sources to understand a new language, students also need to get a clear explanation of new 
words. After they get clear image, they can understand the meaning of the words then memorize them. Finally, the students can use the words to express their ideas.

Nation (1990) as cited in Cameron (2001: 85) also states that teacher can explain the meaning of the word using a basic technique. There are basic techniques that can be used in young learner classroom; by demonstration or pictures teacher can use an object, using a cut-out figure, using gesture or body language, performing an action, photographs, draw or using diagrams on the board, or take a picture from book, teacher also can use moving image from video.

In addition, teaching vocabulary to young learner have to encourage students to think about the word and its meaning using interesting methods and strategies in order to be able remember it. It needs to use an appropriate method. One of appropriate method which can applied in teaching vocabulary to young learner is Total Physical Response (TPR). According to Richard and Rogers (2001: 73) state that Total Physical Response is a language teaching method that is based on coordination between speech and action, it attemps to teach language through physical activity. It is supported by Cameron (2001: 2-3) states that the young learners actively try to construct the meaning from their experiences. Thus, the young learners learn something new by doing activities or experiences. So, teaching vocabulary to young learner will be effective if we used gesture of body language. It means that memorizing a word is done directly by the motor activity.

c. Theory of Game

1) Definition of Game

The game is a fun activity that has a rule and children like to play them. Actually, game is crucial to growth a brain, because game can improve concentration and practice to solve the problem quickly and accurately.Playing game is a natural part of growing up and learning. The game makes children having an experiment, discover and interact with their environment. The game can be used to get students' interest and motivation in English learning.

2) The Advantages of Game

The game can be media that will give many advantages for teacher and the students either. According to Brewster and Ellis (2002: 173), there are some advantages of using games in the classroom: games add variety to the range of learning situations; games change the pace of a lesson and help to keep pupils' motivation; games 'lighten' more formal teaching and can help to renew pupils' energy; games provide 'hidden' practice of specific language patterns, vocabulary, and pronunciation; games can help to improve attention span, concentration, memory, listening and reading skill; pupils are encouraged to participate, shy learners can be motivated to speak; games increase pupil-pupil communication which provides fluency practice and reduces the domination of the class by the teacher; it helps create a fun atmosphere and reduces the distance between teacher and pupils; games can help reveal areas of weakness and the need for further language; games can help to motivate and improve writing skill by providing a real audience context and purpose.

3) Types of Game

There are many types of games. According to Hadfield (1999: 5), there are some types of game in language teaching, namely: information gap games, guessing games, search games, matching Games, labelling games, exchanging games, exchanging and collecting games, board game and card games, and roleplay games. Based on the types of game, the game which is used in this research are 
classified as a guessing game. Because it has the same goal in which the goal is to use guessing to discover some kind of information, such as a word or a phrase.

d. Charades Game

According to Oxford Dictionary (2008: 68), charades means a game in which players guess a word or phrase from a written or acted clue given for each syllable and for the whole item. By the definition about charades, charades game is the activity that players act a word or phrase and their teammates try to guess. Charades game is also called party word guessing game. It is common to require the players to mime their hints without using any spoken words, which require some conventional gestures. Other players try to guess the word as soon as possible, and the team or player who guesses the most wins. According to Harmer (2007: 116), using mime, gesture, and expression to convey meaning are one of the specific ways that can help students to understand language. Thus, mime and gesture probably work best when they are used in teaching vocabulary.

The charades game gives description of vocabulary with body language. For example: in the "activity" material, the teacher gives description about word "riding", the teacher can give the description of the word use body language or do the riding movement directly and their team try to guess.

\section{METHODS}

This research is classified as a experimental research since the title of the research is "The Effectiveness of Charades Game towards Students Vocabulary Mastery at Fourth Grade of SD Unggulan Aisyiyah Bantul in the Academic Year 2016/2017". In this research, the researcher uses two groups. There are experimental group and control group. Experimental group who was taught using charades game and control group who was taught without using charades game. This research was conducted at SD Unggulan Aisyiyah Bantul, Yogyakarta. The population of this research all the fourth grade students at SD Unggulan Aisyiyah Bantul in the academic year 2016/2017. Based on school administration the number of populations are 124 students which consist 31 students of each class. The technique of taking sample used in this research is simple random sampling because the population is homogeneous. It means that the researcher chooses two groups randomly. The researcher decided to take IV $\mathrm{B}$ is as the experimental group and IV $\mathrm{D}$ is as the control group. In collecting data, there are three steps which are conducted by the researcher, namely pre-test, treatments, and post-test. In this research there are two kinds data analysis that will be explained, they are data statistics and inferential statistics.

\section{FINDINGS AND DISCUSSION}

4.1 Data Description

In the data description, the researcher describes and explains the data of the test given to the students in experimental group and control group, then compare both of them to know the difference.

The data description consist of the try-out instrument, pre-test, treatment and post test.

a. The Try-Out Instrument

Before the pre-test was given to the students, a try-out instrument should be tested to know the validity and reliability of intrument. 25 test items were prepared for a try-out instrument. The expert judgement, difficulty index, discrimination index formula were used to determine the validity of the test. After analyzing the 
test using validity and reliability. The result showed that there were 20 items valid and 5 item invalid. And the result of reliability was 0.83 . Based on the criteria of reliability, the reliability was very high.

b. Pre-test

The pre-test was given to both groups on Friday, $21^{\text {st }}$ April 2017. The test topics is choosen based on curriculum; adjectives and activities. The test consists of 20 items of multiple choice. It has done in 30 minutes. All of students in experimental and control group did the pre-test. In the beginner category, some students of both groups have found difficulties in answering the pre-test, while other students did the pre-test well.

c. Treatment

The treatment was given to the experimental group and control group in four meetings on April $28^{\text {th }}$, May $5^{\text {th }}$, May $12^{\text {th }}$ and May $19^{\text {th }}$, 2017. The materials is choosen based on curriculum; adjectives and activities. The materials were taught by using charades game. After that, the student were given an exercise based on material.

For the control group, the students were not taught by using charades game. The teaching process was done on April 28 ${ }^{\text {th }}, 2017$ until May 19 ${ }^{\text {th }}, 2017$. The materials were taught convensionally, giving explanation of the materials then the student were given an exercise based on material.

d. Post-test

The post-test was given to both groups after the treatment on Wednesday, $24^{\text {st }}$ May 2017. The test topics is choosen based on curriculum; adjectives and activities. The test consists of 20 items of multiple choice. It has done in 30 minutes. All of students in experimental and control group did the post-test well.

4.2 Descriptive Analysis

a. Descriptive Analysis of Pre-test

The data are presented based on the result of the pre-test of each group which consists of mean, standard deviation, maximum score, and minimum score.

Table 1: The Descriptive Analysis of Pre-test of Experimental and Control Group Descriptive Statistics of Pre-test

\begin{tabular}{lccccc}
\hline Group & $\begin{array}{c}\text { Number of } \\
\text { Student }\end{array}$ & $\begin{array}{c}\text { Minimum } \\
\text { Score }\end{array}$ & $\begin{array}{c}\text { Maximum } \\
\text { Score }\end{array}$ & Mean & Std. Deviation \\
\hline Experiment & 31 & 20 & 80 & 54.67 & 18.11 \\
\hline Control & 31 & 15 & 80 & 52.25 & 16.57 \\
\hline
\end{tabular}

From the data above, the mean of experimental group (54.67) is higher than the mean of control group (52.25). The standard deviation of experimental group (18.11) is also higher than the standard deviation of control group (16.57). The maximum score of both groups are same (80). The difference also found on minimum score where the control group has lower minimum score (15) than the experimental group (20).

After the descriptive analysis of pre-test of each group, the researcher identifies the frequency distribution to know the level of students' vocabulary mastery of the pre-test using five scales. The summary of the frequency distribution of pre-test scores of the experimental and control group is presented on the table below. 
Table 2: The Frequency Distribution of the Pre-test Score

\begin{tabular}{lcccc}
\hline \multirow{2}{*}{ Category } & \multicolumn{2}{c}{ Experimental } & \multicolumn{2}{c}{ Control } \\
\cline { 2 - 5 } & Frequency & Percentage & Frequency & Percetage \\
\hline Very Good $(\mathbf{8 2 . 5}-\mathbf{1 0 0})$ & 0 & $0 \%$ & 0 & $0 \%$ \\
\hline Good $(\mathbf{6 7 . 5}-\mathbf{8 2 . 5})$ & 10 & $32.3 \%$ & 8 & $25.9 \%$ \\
\hline Fair $(\mathbf{5 2 . 5}-\mathbf{6 7 . 5})$ & 8 & $25.8 \%$ & 7 & $22.6 \%$ \\
\hline Poor $(\mathbf{3 7 . 5}-\mathbf{5 2 . 5})$ & 7 & $22.6 \%$ & 11 & $35.5 \%$ \\
\hline Very Poor $(\mathbf{0}-\mathbf{3 7 . 5})$ & 6 & $19.4 \%$ & 5 & $16.1 \%$ \\
\hline
\end{tabular}

The table above shows that there is no students of both groups $(0 \%)$ in very good category. In good category, there are 10 (32.3\%) students of the experimental group and eight $(25.9 \%)$ students of the control group. There are eight $(25.8 \%)$ students of the experimental group in fair category. While there are also seven (22.6) students of the control group in same category. In poor category, there are seven $(22.6 \%)$ students of the experimental group, it is lower than students of control group that there are $11(35.5 \%)$ students. The difference is also found in very poor category where in the experimental group there are six $(19.4 \%)$ students, while in the control group there are five (16.1\%) students.

b. Descriptive Analysis of Post-test

The data are presented based on the result of post-test of both the experimental and control groups.

Table 3: The Descriptive Analysis of Post-test of Experimental and Control Group Descriptive Statistics of Post-test

\begin{tabular}{lccccc}
\hline Group & $\begin{array}{c}\text { Number of } \\
\text { Students }\end{array}$ & $\begin{array}{c}\text { Minimum } \\
\text { Score }\end{array}$ & $\begin{array}{c}\text { Maximum } \\
\text { Score }\end{array}$ & Mean & Std. Deviation \\
\hline Experiment & 31 & 70 & 100 & 81.77 & 8.01 \\
\hline Control & 31 & 50 & 90 & 70.16 & 10.28 \\
\hline
\end{tabular}

From the data above, the mean of control group (70.16) is lower than the mean of experimental group (81.77), the difference is 11.61. The maximum score of control group (90) is lower than the maximum score of experimental group (100). The control group also has lower minimum score (50) than the experimental group (70). Thus, it can be concluded that the result of post-test of experimental group is better than the result of the control group.

The table below shows the frequency distribution of post-test scores of the experimental and control group.

Table 4: The Frequency Distribution of the Post-test Score

\begin{tabular}{lcccc}
\hline \multirow{2}{*}{\multicolumn{1}{c}{ Category }} & \multicolumn{2}{c}{ Experimental } & \multicolumn{2}{c}{ Control } \\
\cline { 2 - 5 } & Frequency & Percentage & Frequency & Percetage \\
\hline Very Good $(\mathbf{8 2 . 5}-\mathbf{1 0 0})$ & 12 & $38.7 \%$ & 3 & $9.7 \%$ \\
\hline Good $(\mathbf{6 7 . 5}-\mathbf{8 2 . 5})$ & 19 & $61.3 \%$ & 16 & $51.7 \%$ \\
\hline Fair $(\mathbf{5 2 . 5}-\mathbf{6 7 . 5})$ & 0 & $0 \%$ & 10 & $32.2 \%$ \\
\hline Poor $(\mathbf{3 7 . 5}-\mathbf{5 2 . 5})$ & 0 & $0 \%$ & 2 & $6.5 \%$ \\
\hline Very Poor $(\mathbf{0}-\mathbf{3 7 . 5})$ & 0 & $0 \%$ & 0 & $0 \%$ \\
\hline
\end{tabular}

From the table above, there are $12(38.7 \%)$ students of the experimental group and there are only three $(9.7 \%)$ students of the control group in very good category. 
In good category, there are $19(61.3 \%)$ students of the experimental group and there are $16(51.7 \%)$ students of the control group. In fair category, there is no student of the experimental group and $10(32.2 \%)$ students of the control group. There is no student $(0 \%)$ of the experimental group in poor category while there are two $(6.5 \%)$ students of the control group. There is no student of both groups $(0 \%)$ in very poor category.

4.3 The Differences of the Students' Vocabulary Mastery Between the

Experimental Group and Control Group

The comparison of the descriptive analysis of the pre-test and post-test of both groups can be seen at the table.

Table 5: Descriptive Analysis of Pre-test and Post-test of Experimental Group and Control Group

\begin{tabular}{|c|c|c|c|c|}
\hline \multirow{3}{*}{ Description } & \multicolumn{4}{|c|}{ Group } \\
\hline & \multicolumn{2}{|c|}{ Experimental } & \multicolumn{2}{|c|}{ Control } \\
\hline & Pre-test & Post-test & Pre-test & Post-test \\
\hline Number of Student & 31 & 31 & 31 & 31 \\
\hline Mean & 54.67 & 81.77 & 52.25 & 70.16 \\
\hline Standard Deviation & 18.11 & 8.01 & 16.57 & 10.28 \\
\hline Maximum & 80 & 100 & 80 & 90 \\
\hline Minimum & 20 & 70 & 15 & 50 \\
\hline Mean Difference & \multicolumn{2}{|c|}{27.1} & \multicolumn{2}{|c|}{17.91} \\
\hline
\end{tabular}

From the table above, there is a difference of mean improvement between the experimental group and the control group. The mean of experimental group increases 27.1 point, while the mean of control group increases only 17.91 point. The difference is also found in standard deviation of experimental group decreases 10.1 point, while the control group decreases -6.29 .

Based on the mean difference, the conclusion is the students of experimental group has better improvement than the students of control group in learning vocabulary. Thus, there is a significant difference between the experimental group and the control group.

4.4 Inferential Analysis

a. Test of Normality

The test of normality is used to know whether the distribution of pre-test and post-test were normal or not. The researcher uses Chi-Square formula that is analyzed by using SPSS 23.00 to test the data normality. The data is normal if the probability (sig.) is higher than significance level $(\alpha=0.05)$. The result of normality test is shown on table below.

Table 6: The Result of Normality Test

\begin{tabular}{lcccc}
\hline \multirow{2}{*}{ Test Statistics } & \multicolumn{2}{c}{ Experimental Group } & \multicolumn{2}{c}{ Control Group } \\
\cline { 2 - 5 } & Pre-test & Post-test & Pre-test & Post-test \\
\hline Chi-Square & 7.161 & 10.774 & 7.161 & 7.613 \\
\hline Df & 12 & 6 & 12 & 8 \\
\hline Sig. & $\mathbf{0 . 8 4 7}$ & $\mathbf{0 . 0 9 6}$ & $\mathbf{0 . 7 7 2}$ & $\mathbf{0 . 3 1 3}$ \\
\hline Decision & Normal & Normal & Normal & Normal \\
\hline
\end{tabular}

From the table, the data of pre-test in experimental group is normal, because the probability (sig.) is higher than $\alpha(0.847>0.05)$. It is also found that the probability (sig.) of post-test of experimental group $(0.096)>0.05$, so it is normally 
distributed too. The data of pre-test and post-test in control group are normal, because the probability (sig.) of pre-test (0.772) and post test (0.313) are higher than 0.05 . Thus, it can be concluded that the pre-test and post-test are normal.

b. Test of Homogeneity

The homogeneity test is used to find out whether the score of one group has homogeneous variance with the score of another group. The researcher uses the Levene-Statistic test analysis that is analyzed by SPSS 23. The data is homogeneous if probability (sig.) is higher than $\alpha=0.05$. The result of homogeneity test is presented on table.

Table 7: The Result of Homogeneity Test

\begin{tabular}{llllll}
\hline Test & Levene-Statistic & df1 & df2 & Sig. & Decision \\
\hline Pre-Test & 0.457 & 1 & 60 & $\mathbf{0 . 5 0 2}$ & Homogenous \\
\hline Post-Test & 1.903 & 1 & 60 & $\mathbf{0 . 1 7 3}$ & Homogenous \\
\hline
\end{tabular}

Based on the computation on table 13, it is found that the probability (sig.) is of pre-test $(0.502)$ is higher than 0.05 . It means the data variance of the pre-test is homogenous and the data variance of the post-test is also homogenous too because the value of probability (sig.) is 0.173 where is higher than 0.05 . Thus, it can be concluded that the data of pre-test and post-test are homogenous.

c. Test of Hypothesis

In this research, the hypothesis test is analyzed by using SPSS 23.00 with Independent T-test. The researcher uses the null hypothesis $\left(\mathrm{H}_{0}\right)$ and alternative hypothesis $\left(\mathrm{H}_{1}\right)$. The result of hypothesis testing can be seen on the table.

Table 8: The Result of Hypothesis Test

\begin{tabular}{lcccc}
\hline \multicolumn{1}{c}{ Source } & $\mathbf{P}(\mathbf{S i g})$ & $\mathbf{t}_{\text {observe }}$ & Df & $\mathbf{t}_{\text {table }} \mathbf{5 \%}$ \\
\hline Pre-test of Experimental \& Control & 0.585 & 0.549 & 60 & 1.671 \\
\hline Post-test of Experimental \& Control & 0.000 & 4.958 & 60 & 1.671 \\
\hline
\end{tabular}

Based on the table, it is found that on pre-test of both group, the probability ( $\mathrm{sig}$ ) is 0.585 which is higher than 0.05 . Thus, there is no significant different of both groups on the pre-test. After doing the treatment, the result of post-test showed that the probability ( $\mathrm{sig}$ ) is 0.000 which is lower than $0.05(0.000<0.05)$. It means the $\mathrm{H}_{1}$ is accepted and $\mathrm{H}_{0}$ is rejected. From the statement above, hypothesis of this research is accepted. It can be concluded that there is a significant difference in vocabulary mastery between the students who are taught by using charades game and who are taught without using charades game at fourth grade of SD Unggulan Aisyiyah Bantul Yogyakarta in academic year of 2016/2017.

The findings show that charades game is more effective in teaching English, especially vocabulary. The findings indicate that the good improvement in learning vocabulay was obtained by experimental group who were taught by using charades game. The charades game gives students in experimental group opportunities to learn vocabulary by playing game. It makes the lesson more interesting because the students learn in fun way. It is supported by Brewster and Ellis (2002) who stated that games are not only motivating and fun but also can practice for improving vocabulary. Then, using game is more effective in teaching to young learner. As Harmer (2007) stated that the young learner get bored easily. So, game is choosen as an appropriate media to keep students' attention. It is supporeted by Brewster 
and Ellis (2002) who stated that game can help to improve attention, concentration, and memory. Moreover, the charades game is played by giving a non-verbal clue without any spoken language, which require some gestures. That is consistent with Nation (1990) who stated that teacher can explain the meaning of wod using basic techniques, one of them is gesture and body language. The charades game also trains the students to memorize the words because they are asked to guess the words by their understanding. It is in line with Decaricco (2001) who stated that words can not be learned separately between memorizing and understanding. The result of this study is also supported by those relavant studies written by Saryati (2013) and Husna (2014) which conclude that learning vocabulary by guessing the word makes the students easy to remember.

Overall, the result of this study is in tune with those theories which indicate that charades game can be applied to teach vocabulary in the classroom.

\section{CONCLUSION AND SUGGESTIONS}

5.1 Conclusion

After analyzing the data which are presented in the previous chapter, the result can be concluded as follows:

a. The data showed that there is a good improvement in students' vocabulary mastery of the experimental group who was taught by using charades game. Before the treatment, the mean score of experimental group was 54.67 with 80 as the highest score and 20 as the lowest score. After teaching by using charades game, the mean score of the experimental group increased from 54.67 to 81.77 with 100 as the highest score and 70 as the lowest score. It was significantly higher before the treatment was given.

b. In the control group who was taught without using charades game, the result showed that the mean score of pre-test was 52.25. The highest score was 80 and the lowest score was 15 . After teaching vocabulary by using conventional media, the mean score of control group increased from 52.25 to 70.16 . It was slightly higher than the mean score before teaching by conventional media. The highest score of the post-test was 90 and the lowest score was 50 .

c. Based on the result of post-test that analyzed by using Independent T-test, there was a significant difference between the experimental group and control group. It showed that the value of significant (sig.) was 0.000 is lower than 0.05 . It means that the alternative hypothesis (H1) is accepted and the null hypothesis (H0) is rejected. Thus, there is a significant difference in vocabulary mastery between the students who are taught by using charades game and who are taught without using charades game at fourth grade of SD Unggulan Aisyiyah Bantul Yogyakarta in academic year of 2016/2017.

It can be concluded that using charades game is more effective in teaching vocabulary especially for the fourth grade students of SD Unggulan Aisyiyah, Bantul, Yogyakarta.

\subsection{Suggestion}

There are some suggestions in order to improve the quality of teaching and learning English, especially in teaching vocabulary.

a. For English teachers

b. The English teachers are suggested to use charades game in teaching and learning process because the charades game can improve students' vocabulary mastery and make students more interested and enjoy in learning vocabulary.

c. For students 
d. The students can develop their vocabulary by using charades game and make them more active because the learning focuses on students.

e. For other researchers

f. The researcher suggests to other researcher to conduct the similar research with different students' condition or to develop other media that can affect the students' vocabulary mastery.

\section{REFERENCES}

Arikunto, Suharsimi. 2016. Dasar-Dasar Evaluasi Pendidikan (Edisi 2). Jakarta: Bumi Aksara.

Arikunto, Suharsimi. 2014. Prosedur Penelitian, Suatu Pendekatan Praktik. Jakarta: Rineka Cipta.

Brewster, Ellis, and Girard. 2002. The Primary English Teacher's Guide. England: Pearson Education Limited.

Brown, H. D. 2014. Principles of Language Learning and Teaching (Sixth Edition). New York: Pearson Education, Inc.

Bull, Victoria. 2008. Oxford Learner's Pocket Dictionary. New York: Oxford University Press.

Cameron, Lynne. 2001. Teaching Language to Young Learners. UK: Cambridge University Press.

Elizabeth, Eva and Digumarti B. Rao. 2006. Acquisition of English Vocabulary. New Delhi: Discover Publishing House.

Hackman, Sue. 2008. Teaching Effective Vocabulary.___: Department for Children, Schools and Families.

Hadfield, Jill. 1999. Intermediate Vocabulary Games. Spain: Mateu Cromo.

Harmer, J. 2007. The Practice of English Language Teaching (Fourth Edition). England: Pearson Education Limited.

Hatch, E., and C. Brown. 1995. Vocabulary, Semantics, and Language Education. Cambridge: Cambridge University Press.

Lewis, Gordon and G. Bedson. 1999. Games for Children. Oxford: Oxford University Press.

Nunan, David and Caroline T. Linse. 2005. Practical English Language Teaching: Young Learners. New York: McGraw-Hill Companies, Inc.

Pourdana, Natasha. 2014. "Metaphorical Awareness: A New Horizon in Vocabulary Retention by Asian EFL Learners". International Journal of Applied Linguistics \& English Literature. Vol. 3 No. 4: 213-220.

Richards, J., \& Rogers, (2001). Approaches and Methods in Language Teaching. London: Cambridge University Press.

Smaldino, S. E., et al. 2005. Instructional Technology and Media for Learning (eighth ed.). Ohio: Merril Prantice Hall.

Stahl, Steven. A. and W. E. Nagy. 2006. Teaching Word Meanings. London: Lawrence Erlbaum Associates.

Sugiyono. 2009. Metode Penelitian Pendidikan (Pendekatan Kuantitatif, Kualitatif dan $R \& D$ ). Bandung: ALFABETA.

Willis, J. 2008. Teaching the Brain to Read. USA: Association for Supervision and Curriculum Development (ASCD). 